\title{
Front Matter: Volume 7525
}

, "Front Matter: Volume 7525," Proc. SPIE 7525, The Engineering Reality of Virtual Reality 2010, 752501 (3 March 2010); doi: 10.1117/12.859171

SPIE Event: IS\&T/SPIE Electronic Imaging, 2010, San Jose, California, United SPIE. States 


\section{PROCEEDINGS \\ IS\&T / SPIE \\ Electronic Imaging \\ SCIENCE AND TECHNOLOGY}

\section{The Engineering Reality of Virtual Reality 2010}

Ian E. McDowall

Margaret Dolinsky

Editors

21 January 2010

San Jose, California, United States

Sponsored and Published by

IS\&T-The Society for Imaging Science and Technology

SPIE 
The papers included in this volume were part of the technical conference cited on the cover and title page. Papers were selected and subject to review by the editors and conference program committee. Some conference presentations may not be available for publication. The papers published in these proceedings reflect the work and thoughts of the authors and are published herein as submitted. The publishers are not responsible for the validity of the information or for any outcomes resulting from reliance thereon.

Please use the following format to cite material from this book:

Author(s), "Title of Paper," in The Engineering Reality of Virtual Reality 2010, edited by lan E. McDowall, Margaret Dolinsky, Proceedings of SPIE-IS\&T Electronic Imaging, SPIE Vol. 7525, Article CID Number (2010).

ISSN 0277-786X

ISBN 9780819479181

Copublished by

SPIE

P.O. Box 10, Bellingham, Washington 98227-0010 USA

Telephone +1 3606763290 (Pacific Time) · Fax +1 3606471445

SPIE.org

and

IS\&T-The Society for Imaging Science and Technology

7003 Kilworth Lane, Springfield, Virginia, 22151 USA

Telephone +1 7036429090 (Eastern Time) · Fax +1 7036429094

imaging.org

Copyright (C) 2010, Society of Photo-Optical Instrumentation Engineers and The Society for Imaging Science and Technology.

Copying of material in this book for internal or personal use, or for the internal or personal use of specific clients, beyond the fair use provisions granted by the U.S. Copyright Law is authorized by the publishers subject to payment of copying fees. The Transactional Reporting Service base fee for this volume is $\$ 18.00$ per article (or portion thereof), which should be paid directly to the Copyright Clearance Center (CCC), 222 Rosewood Drive, Danvers, MA 01923. Payment may also be made electronically through CCC Online at copyright.com. Other copying for republication, resale, advertising or promotion, or any form of systematic or multiple reproduction of any material in this book is prohibited except with permission in writing from the publisher. The CCC fee code is $0277-786 \mathrm{X} / 10 / \$ 18.00$.

Printed in the United States of America.

Paper Numbering: Proceedings of SPIE follow an e-First publication model, with papers published first online and then in print and on CD-ROM. Papers are published as they are submitted and meet publication criteria. A unique, consistent, permanent citation identifier (CID) number is assigned to each article at the time of the first publication. Utilization of CIDs allows articles to be fully citable as soon they are published online, and connects the same identifier to all online, print, and electronic versions of the publication. SPIE uses a six-digit CID article numbering system in which:

- The first four digits correspond to the SPIE volume number.

- The last two digits indicate publication order within the volume using a Base 36 numbering system employing both numerals and letters. These two-number sets start with 00, 01, 02, 03, 04, 05, 06, 07 , 08, 09, OA, OB ... OZ, followed by 10-1Z, 20-2Z, etc.

The CID number appears on each page of the manuscript. The complete citation is used on the first page, and an abbreviated version on subsequent pages. Numbers in the index correspond to the last two digits of the six-digit CID number. 


\title{
Contents
}

\author{
$\checkmark$ Conference Committee \\ vii Introduction
}

SESSION 1 COLOR ME BEAUTIFUL: PUTTING YOUR BEST IMAGE FORWARD

$752502 \quad$ Hotspot mitigation in the StarCAVE [7525-02]

J. Rhee, J. Schulze, T. A. DeFanti, Univ. of California, San Diego (United States)

752503 A turning cabin simulator to reduce simulator sickness [7525-03]

R. R. Mourant, Z. Yin, Northeastern Univ. (United States)

SESSION 2 WORK IT OUT: USING INTERFACES FOR FACILITATING ABLENESS

$752505 \quad$ Virtual reality welder training [7525-05]

S. A. White, D. Reiners, M. Prachyabrued, C. W. Borst, T. L. Chambers, Univ. of Louisiana at Lafayette (United States)

752506 Exploring the simulation requirements for virtual regional anesthesia training [7525-06] V. Charissis, Glasgow Caledonian Univ. (United Kingdom); C. R. Zimmer, Golden Jubilee Hospital (United Kingdom); S. Sakellariou, Glasgow Royal Infirmary (United Kingdom); W. Chan, Univ. of Glasgow (United Kingdom)

752508 Using commodity accelerometers and gyroscopes to improve speed and accuracy of JanusVF [7525-08]

M. Hutson, D. Reiners, Univ. of Louisiana at Lafayette (United States)

752509 A case study of collaborative facilities use in engineering design [7525-09]

L. Monroe, Los Alamos National Lab. (United States); D. Pugmire, Oak Riadge National Lab. (United States)

\section{SESSION 3 ARTFUL REALITIES AND ENGINEERING EXPERIENCE}

7525 OA Dissociation in virtual reality: depersonalization and derealization [7525-10]

G. P. Garvey, Quinnipiac Univ. (United States)

7525 OB The interplays among technology and content, immersant and VE [7525-11] M. Song, D. Gromala, C. Shaw, Simon Fraser Univ. (Canada); S. J. Barnes, Univ. of British Columbia (Canada)

7525 0C Ambient clumsiness in virtual environments [7525-12]

S. Ruzanka, Indiana Univ. (United States); K. Behar, Pace Univ. (United States)

7525 OD Body parts [7525-13]

E. Ayiter, Sabanci Univ. (Turkey) 
7525 OE The social computing room: a multi-purpose collaborative visualization environment [7525-14]

D. Borland, M. Conway, J. Coposky, W. Ginn, R. Idaszak, The Univ. of North Carolina at Chapel Hill (United States)

7525 OF Experiments in mixed reality [7525-15]

D. M. Krum, R. Sadek, The Univ. of Southern California (United States); L. Kohli, The Univ. of North Carolina at Chapel Hill (United States); L. Olson, M. Bolas, The Univ. of Southern California (United States)

$7525 \mathrm{OH}$ Interactive augmented reality system for product design review [7525-17]

G. Caruso, G. M. Re, Politecnico di Milano (Italy)

7525 Ol Art in virtual reality 2010 [7525-18]

B. Chang, The Art Institute of Chicago (United States)

7525 0J Dream Home: a multiview stereoscopic interior design system [7525-19]

F.-J. Hsiao, C.-J. Teng, C.-W. Lin, A.-C. Luo, J.-C. Yang, Industrial Technology Research Institute (Taiwan)

Author Index 


\title{
Conference Committee
}

\author{
Symposium Chair \\ Jan P. Allebach, Purdue University (United States) \\ Symposium Cochair
}

Sabine Süsstrunk, Ecole Polytechnique Fédérale de Lausanne (Switzerland)

Conference Chairs

Ian E. McDowall, Fakespace Labs, Inc. (United States) Margaret Dolinsky, Indiana University (United States)

Session Chairs

1 Color Me Beautiful: Putting Your Best Image Forward

Ian E. McDowall, Fakespace Labs, Inc. (United States)

2 Work It Out: Using Interfaces for Facilitating Ableness

Margaret Dolinsky, Indiana University (United States)

3 Artful Realities and Engineering Experience

Margaret Dolinsky, Indiana University (United States)

$4 \quad$ Virtual Environments in Action

Ian E. McDowall, Fakespace Labs, Inc. (United States) 
Downloaded From: https://www.spiedigitallibrary.org/conference-proceedings-of-spie on 26 Apr 2023

Terms of Use: https://www.spiedigitallibrary.org/terms-of-use 


\section{Introduction}

Papers this year explore a range of topics including the perceptions of self in virtual environments and the implementation of several techniques for realizing virtual environments in academic settings. Papers regarding the improvement of images in virtual environments included a paper discussing the implementation of shaders to reduce hot-spots on the display walls in the StarCave. A paper from Northwestern looked at the influence of rotation in driving simulation. Papers from the University of Louisiana explored the use of virtual reality tools for developing an interactive trainer for welding. The University of Lovisiana has also been exploring methods for letting one walk (or lope) through virtual environments on an omnidirectional treadmill. Dirk Reiners also presented the incorporation of additional gyroscopic and acceleration based sensors from game controllers to improving the latency and accuracy of a tracker. Laura Monroe from Los Alamos discussed their collaborative VR environments used across a large number of scientists.

The perception of self and others and self perception in virtual environments was explored in the next several papers. The papers included work form Quinnipiac University on dissociation in environments such as Second Life. The extension of ourselves into these electronic imaging medias such as Second Life has a broad impact on the way we perceive ourselves and others. These and other thoughts were explored in a wonderfully lyrical presentation by Silvia Ruzanka and Katherine Behar. One of the key realizations and ideas presented was that because something occurred in a virtual environment does not mean that it was not real to the participants in that electronic interchange of images, audio, and ultimately human expression. Work was also presented from Sabanci University on the perception and presentation of the body in these electronic media.

The final session presented work from The University of North Carolina showing a very compelling way to interact with a large multi-projector array which wrapped around a room and could be used as a presentation surface. A paper from the University of Southern California presented work with the Army and Marines on mixed reality training environments and experiments designed to improve the VR training tools available to such forces. A paper from the Industrial Technology Research Institute in Taiwan presented an interesting catalog with an augmented reality interface for exploring furniture. Benjamin Chang from the Art Institute in Chicago discussed the artistic nature of virtual environments. The day concluded with a live demonstration including artwork from several artists presented on a rear projection stereo display with tracked interaction.

Ian E. McDowall Margaret Dolinsky 
Downloaded From: https://www.spiedigitallibrary.org/conference-proceedings-of-spie on 26 Apr 2023

Terms of Use: https://www.spiedigitallibrary.org/terms-of-use 